\title{
Clinical verification of sensitivity to preoperative chemotherapy in cases of androgen receptor-expressing positive breast cancer
}

\author{
Yuka Asano ${ }^{1}$, Shinichiro Kashiwagi ${ }^{\star, 1}$, Naoyoshi Onoda ${ }^{1}$, Kento Kurata ${ }^{1}$, Tamami Morisaki ${ }^{1}$, Satoru Noda ${ }^{1}$, \\ Tsutomu Takashima1, Masahiko Ohsawa ${ }^{2}$, Seiichi Kitagawa ${ }^{3}$ and Kosei Hirakawa ${ }^{1}$ \\ ${ }^{1}$ Department of Surgical Oncology, 1-4-3 Asahi-machi, Abeno-ku, Osaka 545-8585, Japan; ${ }^{2}$ Department of Diagnostic Pathology, \\ 1-4-3 Asahi-machi, Abeno-ku, Osaka 545-8585, Japan and ${ }^{3}$ Department of Physiology, Osaka City University Graduate School of \\ Medicine, 1-4-3 Asahi-machi, Abeno-ku, Osaka 545-8585, Japan
}

\begin{abstract}
Background: Triple-negative breast cancer (TNBC) patients testing positive for androgen receptor (AR) expression are thought to be chemotherapy resistant, similar to other hormone receptor-positive breast cancers; however, this has not been substantially validated in the clinic. In this study, we investigated the association between chemotherapy sensitivity and AR expression in patients treated with neoadjuvant chemotherapy (NAC) using standardised chemotherapy criteria and regimens.
\end{abstract}

Methods: A total of 177 patients with resectable early-stage breast cancer were treated with NAC. Oestrogen receptor, progesterone receptor, HER2, Ki67 and AR status were assessed immunohistochemically.

Results: Sixty-one patients were diagnosed with TNBC; AR expression was identified in 23 (37.7\%), which was significantly less common than that found in non-TNBC patients (103 of 116; 88.8\%; $P<0.001$ ). The rate of pathological complete response after NAC was significantly lower $(P=0.001)$, and disease recurrence was more common $(P=0.008)$ in patients with AR-positive compared with those with AR-negative TNBC. In TNBC cases, as expected, the non-recurrence period in cases that were negative for AR expression was significantly extended ( $P=0.006$, log-rank).

Conclusions: Androgen receptor expressions may be useful as biomarkers to predict treatment responses to NAC in TNBC. Moreover, induction of a change in subtype to the AR-negative phenotype was observed after NAC.

Breast cancer is a typical hormone-dependent malignant tumour. Expression of the oestrogen receptor (ER) is frequently observed in breast cancer and plays a central role in disease development and progression. In addition, expression of the androgen receptor (AR) has also been frequently noted, suggesting that androgens may also play a role in breast cancer biodynamics (Soreide et al, 1992; Isola, 1993; Kuenen-Boumeester et al, 1996; Brys et al, 2002; Moinfar et al, 2003; Ogawa et al, 2008). Androgen receptor expression has been identified in $70-90 \%$ of breast tumours, similar to the frequency of ER expression (Hall and Solehdin, 1996; KuenenBoumeester et al, 1996). Although previous reports indicate that androgens inhibit the progression of breast cancer (Poulin et al, 1988; de Launoit et al, 1991; Ando et al, 2002), the precise mechanisms and clinical significance of AR in breast cancer remain unclear.

The diversity of breast cancer subtypes is exemplified by the differential sensitivity of various individuals to chemotherapy. Genetic analysis using cDNA microarrays revealed that breast cancer may be categorised into multiple groups based on clinical differences: five breast cancer intrinsic subtypes (luminal A, luminal B, human epidermal growth factor receptor type (HER) 2 enriched, claudin-low, basal like) and a normal breast-like group (Perou et al, 2000; Abd El-Rehim et al, 2005; Mattie et al, 2006; Prat and Perou, 2011). Among these, the basal-like subtype exhibits characteristics similar to myoepithelial/basal cells, with

*Correspondence: S Kashiwagi; E-mail: spqv9ke9@view.ocn.ne.jp

Received 9 May 2015; revised 16 September 2015; accepted 6 November 2015

(c) 2016 Cancer Research UK. All rights reserved 0007-0920/16

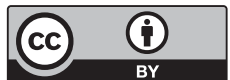


many cases consistent with triple-negative breast cancer (TNBC), in that they are immunohistochemically ER negative, progesterone receptor $(\mathrm{PgR})$ negative and HER2 negative. For this reason, endocrine therapy and anti-HER2 therapy are unlikely to be effective, leaving chemotherapy as the only alternative (Sorlie et al, 2001, 2003; Nielsen et al, 2004; Rakha et al, 2006; Bauer et al, 2007).

Given the lack of treatment choices and the biological attributes of TNBC, this type of breast cancer generally has a poor prognosis, and new therapeutic targets are being investigated (Lehmann et al, 2011; Metzger-Filho et al, 2012; Masuda et al, 2013). Previous studies indicate that AR expression could be a potential target for anti-androgen therapy in TNBC (Safarpour and Tavassoli, 2014). Similarly, AR-expressing TNBC has been considered chemotherapy resistant from observations from preclinical experiments (Graham et al, 2010; Lehmann et al, 2011), similar to ER-positive breast cancer. However, few studies have verified the efficacy of chemotherapy in patients with AR-positive TNBC at the clinical level. In neoadjuvant chemotherapy (NAC) cases, we hypothesised that the pathological complete response $(\mathrm{pCR})$ rate would decrease if AR-positive TNBC showed chemoresistance.

In the present study, we retrospectively investigated the outcomes of NAC in patients with TNBC, using standardised criteria and regimens. The aim of this study was to clarify the differences in chemosensitivity, clinically and pathologically, based on AR expression in patients with breast cancer.

\section{MATERIALS AND METHODS}

Patients. A total of 177 patients with resectable early-stage breast cancer diagnosed as stage IIA (T1, N1, M0 or T2, N0, M0), IIB (T2, $\mathrm{N} 1, \mathrm{M} 0$ or $\mathrm{T} 3, \mathrm{~N} 0, \mathrm{M} 0)$ or IIIA (T1-2, N2, M0 or T3, N1-2, M0) were treated with NAC between 2007 and 2013. Tumour stage and $\mathrm{T}$ and $\mathrm{N}$ factors were stratified based on the TNM Classification of Malignant Tumours, UICC Seventh Edition (Ainbinder et al, 2009). Breast cancer was confirmed histologically using core needle biopsies and staged using systemic imaging studies employing computed tomography (CT), ultrasonography (US) and bone scintigraphy. Breast cancer was classified into subtypes according to the immunohistochemical expression of ER, PgR, HER2 and Ki67. Based on their immunohistochemical expression, the tumours are categorised into the immunophenotypes luminal A $(\mathrm{ER}+$ and/or PgR,+ HER $2-$, Ki67-low), luminal B (ER + and/or PgR,+ HER $2+)($ ER + and/or PgR,+ HER2 - , Ki67-high $)$, HER2-enriched (HER2BC) (ER - , PgR - , and HER2 + ) and TNBC (negative for ER, PgR and HER2). In this study, luminal A and luminal $\mathrm{B}$ were considered as hormone receptor-positive breast cancer (HRBC).

All patients received a standardised protocol of NAC consisting of four courses of FEC100 $\left(500 \mathrm{mg} \mathrm{m}^{-2}\right.$ fluorouracil, $100 \mathrm{mg} \mathrm{m}^{-2}$ epirubicin and $500 \mathrm{mg} \mathrm{m}^{-2}$ cyclophosphamide) every 3 weeks, followed by 12 courses of paclitaxel $\left(80 \mathrm{mg} \mathrm{m}^{-2}\right)$, administered weekly (Mauri et al, 2005; Mieog et al, 2007; Kawajiri et al, 2012). Forty-five patients were diagnosed with HER2-positive breast cancer and trastuzumab was administered on a weekly $\left(2 \mathrm{mg} \mathrm{kg}^{-1}\right)$ or tri-weekly $\left(6 \mathrm{mg} \mathrm{kg}^{-1}\right)$ basis, during paclitaxel treatment (Buzdar et al, 2007). All patients underwent chemotherapy as outpatients. Therapeutic antitumour effects were assessed according to the Response Evaluation Criteria in Solid Tumours (RECIST) criteria (Perez et al, 2013). Pathological complete response ( $\mathrm{pCR}$ ) was defined as the complete disappearance of the invasive compartment of the lesion with or without intraductal components, including the lymph nodes. Patients underwent mastectomy or breast-conserving surgery after NAC. All patients who underwent breast-conserving surgery were administered postoperative radiotherapy to the remnant breast. We operated on seven cases with progressive disease occurring during NAC treatment. Overall survival (OS) was defined as the period from the initiation of NAC to the time of death from any cause. Disease-free survival (DFS) was defined as the period in years, from the date of the primary surgery to the first local recurrence, distant recurrence or death from any cause. All patients were followed up with physical examinations every 3 months, US every 6 months and CT and bone scintigraphy annually. The median follow-up period for the assessment of OS was 3.4 years (range, 0.6-6.0 years) and 3.1 years for DFS (range, 0.1-6.0 years). One aspect of the study involved retrospective chart review. Written informed consent was obtained from all subjects. This research conformed to the provisions of the Declaration of Helsinki adopted in 1995. All patients were informed of the investigational nature of this study and provided their written, informed consent. The Ethics Committee of Osaka City University approved the study protocol (\#926).

Immunohistochemistry. All patients had a core needle biopsy prior to receiving NAC, and following treatment underwent either a mastectomy or breast-conserving surgery with axillary lymph node dissection at Osaka City University. Immunohistochemical studies on core needle biopsy specimens were performed as previously described (Kashiwagi et al, 2013). Tumour specimens were fixed in $10 \%$ formaldehyde solution and embedded in paraffin, and 4 - $\mu$ m-thick sections were mounted onto glass slides. Slides were deparaffinised in xylene and heated for $20 \mathrm{~min}$ in Target Retrieval Solution (Dako, Carpinteria, CA, USA) in an autoclave $\left(105^{\circ} \mathrm{C}, 0.4 \mathrm{~kg} \mathrm{~m}^{-2}\right)$. Specimens were then incubated with $3 \%$ hydrogen peroxide in methanol for $15 \mathrm{~min}$ to block the endogenous peroxidase activity, and then incubated in $10 \%$ normal goat or rabbit serum to block non-specific reactions.

Primary monoclonal antibodies directed against ER (clone 1D5, dilution 1:80; Dako), PgR (clone PgR636, dilution 1:100; Dako), HER2 (HercepTest; Dako), Ki67 (clone MIB-1, dilution 1:00; Dako) and AR (clone AR441, dilution 1:100; Dako) were used. Tissue sections were incubated with each antibody for $70 \mathrm{~min}$ at room temperature or overnight at $4{ }^{\circ} \mathrm{C}$, and then incubated with horseradish peroxidase-conjugated anti-rabbit or anti-mouse IgG secondary antibodies (HISTOFINE (PO) kit; Nichirei, Tokyo, Japan). Slides were subsequently treated with a streptavidinperoxidase reagent and incubated in phosphate-buffered salinediaminobenzidine and $1 \%$ hydrogen peroxide $(\mathrm{v} / \mathrm{v})$, followed by counterstaining with Mayer's haematoxylin. Positive and negative controls for each marker were used according to the supplier's data sheet.

Immunohistochemical scoring. Immunohistochemical scoring was performed by two pathologists specialised in mammary gland pathology, using the blind method to confirm the objectivity and reproducibility of each diagnosis. The cut-off value for ER and PgR positivity was set at $\geqslant 1 \%$ in accordance with previous studies (Umemura et al, 2006), and the same cut-off was also adopted for AR positivity (Castellano et al, 2010; Luo et al, 2010). HER2 expression was scored according to the accepted grading system $(0$, no reactivity or membranous reactivity in less than $10 \%$ of cells; $1+$, faint/barely perceptible membranous reactivity in $\geqslant 10 \%$ of cells or reactivity in only part of the cell membrane; $2+$, weak to moderate complete or basolateral membranous reactivity in $\geqslant 10 \%$ of tumour cells; or $3+$, strong complete or basolateral membranous reactivity in $\geqslant 10 \%$ of tumour cells). HER 2 expression was considered positive if the immunostaining score was $3+$, or in cases where the score was $2+$, gene amplification was determined via fluorescent in situ hybridisation (FISH). For FISH analysis, each copy of the HER2 gene and its centromere 17 (CEP17) reference were counted. Interpretation of the results followed the 
criteria of the ASCO/CAP guidelines for HER2 IHC classification for breast cancer: positive if the HER2/CEP17 ratio was $>2.0$ (Wolff et al, 2013, 2014). A Ki67-labelling index of $\geqslant 14 \%$ was classified as positive (Goldhirsch et al, 2011). Androgen receptor expression was semiquantitatively analysed according to the percentage of cells showing positive staining in the nucleus: 0 , $0 \% ; 1+, 1-29 \% ; 2+, 30-69 \% ; 3+, \geqslant 70 \%$. Androgen receptor expression was considered positive when scores were $\geqslant 1$, and negative when scores were 0 (Figure 1).

Statistical analysis. Statistical analysis was performed using the SPSS version 19.0 statistical software package (IBM, Armonk, NY, USA). Categorical data are reported with numbers and percentages, and continuous data as median and range. The association between $\mathrm{AR}$ and other clinicopathologic variables, and the significance of different prognostic markers were analysed using the chi-squared test (or Fisher's exact test when necessary). The association with survival was analysed using the Kaplan-Meier plot and log-rank test. The Cox proportional hazards model was used to compute univariable and multivariable hazard ratios (HR) for the study parameters with $95 \%$ confidence intervals, and used in a backward stepwise method for variable selection in multivariate analysis. In all of the tests, a $P$-value of less than 0.05 was considered statistically significant. Cut-off values for different biomarkers included in this study were chosen before statistical analysis.

\section{RESULTS}

The breast cancer subtypes of the 177 patients who received NAC were as follows: $61(34.5 \%)$ were TNBC, 36 (20.3\%) were HER2BC and 80 (45.2\%) were HRBC (non-TNBC; HER2BC and HRBC). Androgen receptor expression was observed in 126 cases (71.2\%). Among the 61 cases of TNBC, AR expression was positive in 23 cases (37.7\%) and negative in 38 cases $(62.3 \%)$. Among the 116 cases of non-TNBC, AR expression was positive in 103 cases $(88.8 \%)$ and negative in 13 cases $(11.2 \%)$ (HER2BC, positive in 30 cases and negative in 6 cases; HRBC, positive in 73 cases and negative in 7 cases). Androgen receptor expression was more commonly observed in patients with non-TNBC $(P<0.001)$ and HRBC $(P<0.001)$, but was not more commonly observed in patients with HER2BC $(P=0.071)$. There was no significant
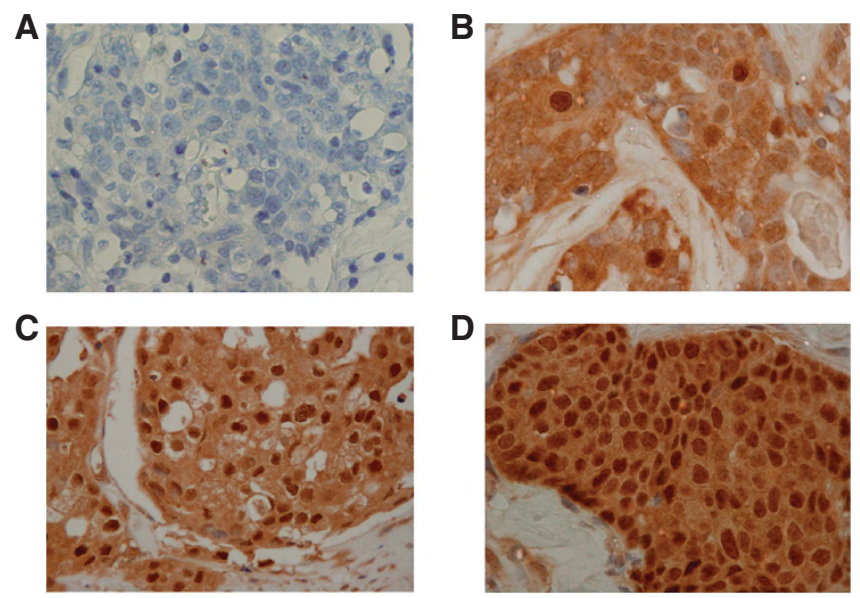

Figure 1. Immunohistochemical analysis of androgen receptor (AR) expression. AR expression was semiquantitatively analysed according to the percentage of cells showing positive expression in the nucleus: $0,0 \%(A) ; 1+, 1-29 \%(B) ; 2+, 30-69 \%(C) ; 3+, \geqslant 70 \%$ (D). Androgen receptor expression was considered positive when scores were $\geqslant 1$, and negative when scores were 0 . difference in relation to other factors including pCR $(P=0.108)$ for all breast cancer subtypes (Table 1). In contrast, analysis of the 61 TNBC cases revealed that the rate of pCR was significantly lower for patients in the AR-positive group $(P=0.001$; Table 2). However, there was no significant difference between AR and PCR in HER2BC $(P=0.052)$ and HRBC $(P=0.056)$ patients.

Analysis of all 177 patients receiving NAC revealed that no significant difference in DFS was associated with AR expression $(P=0.090$, log-rank; Figure 2A). Similarly, no significant difference in DFS was associated with AR expression in patients with non-TNBC $(P=0.628, \log$-rank; Figure $2 \mathrm{~B})$. However, a significantly shortened non-recurrence period was observed in patients with AR-expressing tumours, when the analysis was limited to patients with TNBC ( $P=0.006, \log$-rank; Figure 2C). Analysis of OS demonstrated similar observations according to the subtypes and AR expression status of the breast cancer (Figure $3 \mathrm{~A}-\mathrm{C}$ ). In univariate analysis, negative $\mathrm{AR}$ expression made a significant contribution to extending DFS in patients with TNBC $(P=0.014, \mathrm{HR}=5.26)$. However, multivariate analysis

Table 1. Correlation between clinicopathological features and androgen receptor expression in 177 breast cancers

\section{.}

\begin{tabular}{|c|c|c|c|}
\hline Parameters & $\begin{array}{c}\text { Positive } \\
(n=126)\end{array}$ & $\begin{array}{c}\text { Negative } \\
(n=51)\end{array}$ & $P$-value \\
\hline \multicolumn{4}{|c|}{ Age at operation } \\
\hline$\leqslant 56$ & $64(50.8 \%)$ & $23(45.1 \%)$ & \\
\hline$>56$ & $62(49.2 \%)$ & 28 (54.9\%) & 0.492 \\
\hline \multicolumn{4}{|l|}{ Menopause } \\
\hline Negative & $52(41.3 \%)$ & $20(39.2 \%)$ & \\
\hline Positive & 74 (58.7\%) & $31(60.8 \%)$ & 0.801 \\
\hline \multicolumn{4}{|l|}{ Tumour size } \\
\hline$\leqslant 2 \mathrm{~cm}$ & $18(14.3 \%)$ & $6(11.8 \%)$ & \\
\hline$>2 \mathrm{~cm}$ & $108(85.7 \%)$ & 45 (88.2\%) & 0.657 \\
\hline \multicolumn{4}{|c|}{ Lymph node status } \\
\hline Negative & $33(26.2 \%)$ & 8 (15.7\%) & \\
\hline Positive & $93(73.8 \%)$ & 43 (84.3\%) & 0.134 \\
\hline \multicolumn{4}{|c|}{ Nuclear grade } \\
\hline 1,2 & 98 (77.8\%) & 39 (76.5\%) & \\
\hline 3 & $28(22.2 \%)$ & $12(23.5 \%)$ & 0.851 \\
\hline \multicolumn{4}{|l|}{ Ki67 } \\
\hline$\leqslant 14 \%$ & $60(47.6 \%)$ & $14(27.5 \%)$ & \\
\hline$>14 \%$ & $66(52.4 \%)$ & 37 (72.5\%) & 0.014 \\
\hline \multicolumn{4}{|c|}{ Intrinsic subtype } \\
\hline TNBC & $23(18.3 \%)$ & 38 (74.5\%) & \\
\hline Non-TNBC & $103(81.7 \%)$ & 13 (25.5\%) & $<0.001$ \\
\hline \multicolumn{4}{|c|}{ Intrinsic subtype } \\
\hline HER2BC & $30(23.8 \%)$ & $6(11.8 \%)$ & \\
\hline Non-HER2BC & $96(76.2 \%)$ & 45 (88.2\%) & 0.071 \\
\hline \multicolumn{4}{|c|}{ Intrinsic subtype } \\
\hline HRBC & 73 (57.9\%) & 7 (13.7\%) & \\
\hline Non-HRBC & $53(42.1 \%)$ & $44(86.3 \%)$ & $<0.001$ \\
\hline \multicolumn{4}{|c|}{ Pathological response } \\
\hline $\mathrm{pCR}$ & $43(34.1 \%)$ & $24(47.1 \%)$ & \\
\hline Non-pCR & $83(65.9 \%)$ & 27 (52.9\%) & 0.108 \\
\hline \multicolumn{4}{|c|}{$\begin{array}{l}\text { Abbreviations: } A R=\text { androgen receptor; } T N B C=\text { triple-negative breast cancer; } H E R 2 B C= \\
\text { human epidermal growth factor receptor } 2 \text {-enriched breast cancer; } H R B C=\text { hormone } \\
\text { receptor-positive breast cancer; } P C R=\text { pathological complete response. }\end{array}$} \\
\hline
\end{tabular}


Table 2. Correlations between androgen receptor expression and clinicopathological parameters in 61 triple-negative, 36 HER2 enriched and 80 luminal type breast cancers

\begin{tabular}{|c|c|c|c|c|c|c|c|c|c|}
\hline & \multicolumn{2}{|c|}{ TNBC $(n=61)$} & & \multicolumn{2}{|c|}{ HER2BC $(n=36)$} & \multicolumn{3}{|c|}{ HRBC $(n=80)$} & $P$-value \\
\hline$\leqslant 56$ & $10(43.5 \%)$ & 15 (39.5\%) & & $14(46.7 \%)$ & $4(66.7 \%)$ & & $40(54.8 \%)$ & $4(57.1 \%)$ & \\
\hline$>56$ & $13(56.5 \%)$ & $23(60.5 \%)$ & 0.195 & $16(53.3 \%)$ & 2 (33.3\%) & 0.371 & $33(45.2 \%)$ & $3(42.9 \%)$ & 0.905 \\
\hline \multicolumn{10}{|l|}{ Menopause } \\
\hline Positive & $13(56.5 \%)$ & $26(68.4 \%)$ & 0.348 & $18(60.0 \%)$ & $1(16.7 \%)$ & 0.133 & $43(58.9 \%)$ & $4(57.1 \%)$ & 0.928 \\
\hline \multicolumn{10}{|l|}{ Tumour size } \\
\hline$\leqslant 2 \mathrm{~cm}$ & $1(4.3 \%)$ & $6(15.8 \%)$ & & $10(33.3 \%)$ & $0(0.0 \%)$ & & $7(9.6 \%)$ & $0(0.0 \%)$ & \\
\hline$>2 \mathrm{~cm}$ & $22(95.7 \%)$ & $32(84.2 \%)$ & 0.174 & $20(66.7 \%)$ & $6(100.0 \%)$ & 0.096 & $66(90.4)$ & 7 (100.0\%) & 0.391 \\
\hline \multicolumn{10}{|c|}{ Lymph node status } \\
\hline 3 & 7 (30.4\%) & $10(26.3 \%)$ & 0.728 & 9 (30.0\%) & $1(16.7 \%)$ & 0.506 & $12(16.4 \%)$ & $1(14.3 \%)$ & 0.883 \\
\hline \multicolumn{10}{|l|}{ Ki67 } \\
\hline$\leqslant 14 \%$ & $9(39.1 \%)$ & 9 (23.7\%) & & $20(66.7 \%)$ & $3(50.0 \%)$ & & $31(42.5 \%)$ & $2(28.6 \%)$ & \\
\hline$>14 \%$ & $14(60.9 \%)$ & $29(76.3 \%)$ & 0.200 & $10(33.3 \%)$ & $3(50.0 \%)$ & 0.438 & $42(57.5 \%)$ & $5(71.4 \%)$ & 0.476 \\
\hline \multicolumn{10}{|c|}{ Pathological response } \\
\hline PCR & $4(17.4 \%)$ & 24 (63.2\%) & & 13 (43.3\%) & $0(0.0 \%)$ & & $26(35.6 \%)$ & $0(0.0 \%)$ & \\
\hline Non-pCR & 19 (82.6\%) & 14 (36.8\%) & 0.001 & 17 (56.7\%) & $6(100.0 \%)$ & 0.052 & 47 (64.4\%) & 7 (100.0\%) & 0.056 \\
\hline
\end{tabular}
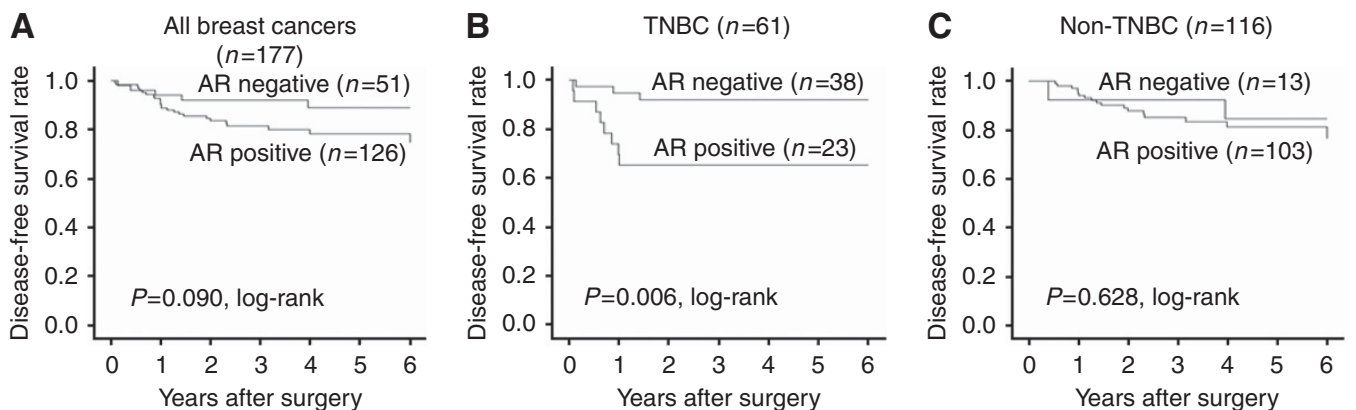

Figure 2. Analysis of all 177 patients treated with neoadjuvant chemotherapy (NAC) revealed no significant difference in disease-free survival (DFS) associated with AR expression ( $P=0.090$, log-rank) (A). No significant difference in DFS according to AR expression was observed in patients with non-TNBC ( $P=0.628$, log-rank) (B). A significantly shortened non-recurrence period was observed in patients with AR-expressing tumours, when the analysis was limited to patients with $\operatorname{TNBC}(P=0.006$, log-rank) (C).
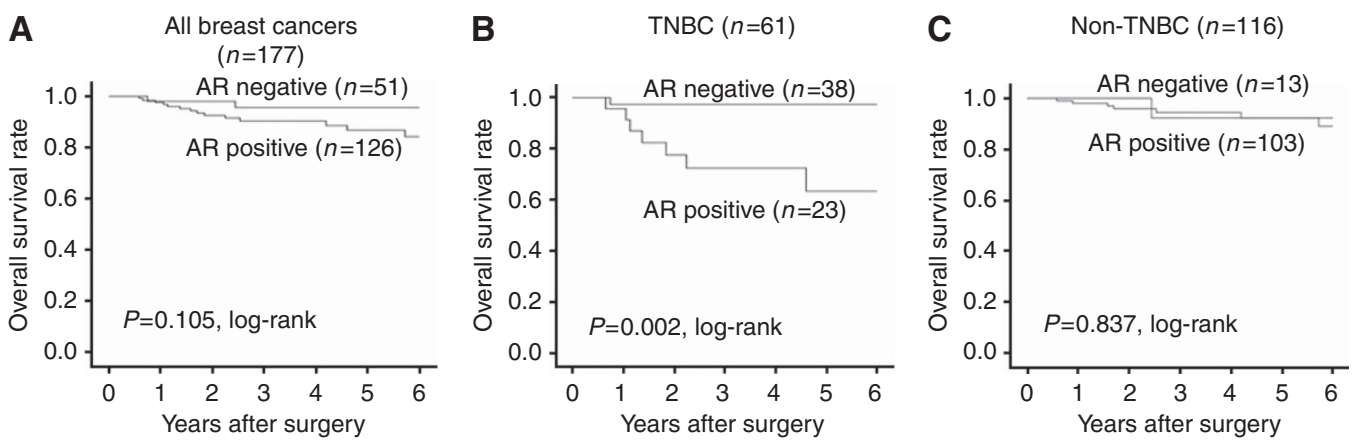

Figure 3. Analysis of overall survival (OS) revealed similar observations according to the subtypes and AR expression status of the breast cancer (A-C). 
Table 3. Univariable- and multivariable analysis with respect to disease-free survival in 61 triple-negative breast cancers

\begin{tabular}{|l|c|c|c|c|c|c|}
\cline { 2 - 5 } & \multicolumn{3}{c|}{ Univariable analysis } \\
\hline Parameter & Hazard ratio & $95 \%$ Cl & P-value & Hazard ratio & $95 \%$ Cl & $P$-value \\
\hline $\begin{array}{l}\text { Lymph node status } \\
\text { Negative vs Positive }\end{array}$ & 0.94 & $0.20-0.94$ & 0.939 & 1.15 & $0.25-5.44$ \\
\hline $\begin{array}{l}\text { Pathological response } \\
\text { pCR vs non-pCR }\end{array}$ & 0.23 & $0.05-1.08$ & 0.063 & 0.45 & $0.08-2.46$ & 0.356 \\
\hline $\begin{array}{l}\text { Androgen receptor } \\
\text { Positive vs Negative }\end{array}$ & 5.26 & $1.39-19.86$ & 0.014 & 3.78 & $0.85-16.68$ & 0.080 \\
\hline Abbreviations: $\mathrm{pCR}=$ pathological complete response; Cl. = confidence interval. &
\end{tabular}

Table 4. The clinical background of 11 patients with AR-positive TNBC recurred

\begin{tabular}{|c|c|c|c|c|c|c|c|c|c|c|c|}
\hline No & Age & Menopause & $\begin{array}{c}\text { Tumour } \\
\text { size }(\mathrm{cm})\end{array}$ & $\begin{array}{c}\text { Lymph } \\
\text { node } \\
\text { status }\end{array}$ & $\begin{array}{c}\text { Nuclear } \\
\text { grade }\end{array}$ & Ki67 (\%) & $\begin{array}{c}\text { Pathological } \\
\text { response }\end{array}$ & $\begin{array}{l}\text { Disease- } \\
\text { free } \\
\text { interval } \\
\text { (years) }\end{array}$ & $\begin{array}{c}\text { AR expression } \\
\text { of CNB } \\
\text { specimens } \\
\text { before NAC }\end{array}$ & $\begin{array}{c}\text { AR expression } \\
\text { of surgical } \\
\text { specimens } \\
\text { after NAC }\end{array}$ & $\begin{array}{c}\text { AR expression } \\
\text { of CNB } \\
\text { specimens after } \\
\text { recurrence }\end{array}$ \\
\hline 2 & 40 & Negative & 3.2 & Negative & 3 & 75 & $\mathrm{pCR}$ & 0.76 & Positive & NA & Positive \\
\hline 3 & 39 & Negative & 3.1 & Positive & 3 & 67 & Non-pCR & 0.99 & Positive & Positive & Negative \\
\hline 6 & 65 & Positive & 2.5 & Positive & 3 & 71 & Non-pCR & 1.01 & Positive & Positive & NA \\
\hline 7 & 58 & Positive & 2.2 & Positive & 2 & 57 & Non-pCR & 0.63 & Positive & Positive & NA \\
\hline 8 & 44 & Negative & 1.8 & Positive & 2 & 82 & Non-pCR & 0.54 & Positive & Negative & Negative \\
\hline 9 & 68 & Positive & 1.6 & Positive & 1 & 12 & Non-pCR & 0.88 & Positive & Negative & Negative \\
\hline
\end{tabular}

revealed that negative AR expression was not an independent factor $(P=0.080, \mathrm{HR}=3.78$; Table 3$)$.

Overall, 11 patients experienced recurrence events among the 23 patients with AR-positive TNBC (Table 4). The disease-free intervals were $0.10-1.42$, with a median of 0.76 years. In three patients, recurrence occurred in the lung and liver (two cases). The remaining eight cases experienced disease recurrence either in the axillary lymph nodes or at the chest wall. Tissue samples of recurrent tumours were obtained from eight patients, and AR expression was confirmed in only two cases. Androgen receptor expression was not detected in the three recurrent foci previously shown to be negative in their surgical specimens.

\section{DISCUSSION}

Triple-negative breast cancer is typically associated with poor prognosis, based on the limited treatment options and the biological attributes of TNBC itself. At present, the NCCN guidelines and St Gallen Consensus conference also consider chemotherapy to be the only alternative for treatment. Despite this, a significantly higher rate of $\mathrm{pCR}$ is observed in TNBC patients following treatment with NAC compared with HRBC patients, with reports also suggesting that patients achieving pCR also demonstrated an extended period of non-recurrence (Masuda et al, 2013). Thus, in patients with TNBC, pCR is considered a useful surrogate marker to indicate the outcome of NAC. In this study, we observed that patients with AR-expressing TNBC had significantly lower rates of $\mathrm{pCR}$, more common recurrence events and poorer prognosis than those with AR-negative TNBC. Our findings were in line with previous observations, suggesting that AR-positive
TNBC is chemoresistant (Gucalp and Traina, 2010; Gucalp et al, 2013).

We observed frequent disease recurrence in patients with ARpositive TNBC. The disease-free intervals in these cases were very short, showing the typical pattern of recurrence in TNBC. We also observed frequent loss of $\mathrm{AR}$ expression in postoperative specimens after NAC, or in the recurrent foci of AR-positive TNBC in these patients, which might be due to the genetically unstable nature of TNBC during disease progression (Wang et al, 2014) or to accelerated genetic instability following NAC.

In our previous study, we demonstrated favourable prognosis in patients with AR-positive TNBC compared with those with AR-negative TNBC, following standard therapeutic strategies. Similar observations have been demonstrated in other studies (Moinfar et al, 2003; Gucalp et al, 2013). The present study demonstrates a different outcome in patients with AR-positive TNBC following NAC. In preclinical studies, it was reported that E-cadherin expression was inversely related to $\mathrm{AR}$ expression in TNBC (Graham et al, 2010). E-cadherin expression was reduced by AR expression in TNBC, and epithelial-mesenchymal transition (EMT) was induced and may show drug resistance.

Recent research indicates that TNBC can be categorised into seven specific subcategories based on genetic expression profiles (Lehmann et al, 2011; Metzger-Filho et al, 2012; Masuda et al, 2013). These include basal-like 1 , basal-like 2 , immunomodulatory, mesenchymal, mesenchymal-stem-like, luminal androgen receptor (LAR) and unstable cluster. Luminal androgen receptor is a subtype in which androgen signalling plays an important role in the cancer cell growth and progression (Gucalp and Traina, 2010). Furthermore, AR-positive TNBC has been reported to have similar genetic expression profiles compared with ER-positive breast cancer, and new, individually tailored treatments such as anti- 
androgen preparations that are currently in phase II testing are expected to show clinical benefit (Gucalp et al, 2013).

Given the results of this study, which indicate that AR-positive TNBC has low sensitivity to chemotherapy, AR-targeted-endocrine therapy may be one such promising therapeutic strategy. It is also known that AR and ER interact. Panet-Raymond et al (2000) demonstrated that the transcriptional activity of AR was inhibited by ER in vitro. In hormone-dependent breast cancer cells, induction of $7 \beta H S D 2$ mRNA by active androgen dihydrotestosterone was inhibited by oestradiol (Takagi et al, 2010). These reports indicate insufficient AR activation by androgen in the presence of oestrogen, even in AR-positive cases, suggesting that AR-positive TNBC is an optimal candidate for antiandrogen therapy. In this study, we investigated changes in $A R$ expression among AR-positive TNBC recurrences, and found that in many cases, $\mathrm{AR}$ expression in the tissue was lost at recurrence, indicating that AR expression was an inhibitory factor in TNBC.

The aim of this study was to clarify, based on AR expression in patients with breast cancer, the differences in chemosensitivity, clinically and pathologically. The pCR rate was significantly higher in AR-negative than in AR-positive patients with TNBC. Our study demonstrates that AR-negative TNBC patients receiving NAC under standardised protocols consisting of FEC, followed by weekly paclitaxel, do not show any survival benefit compared with patients with AR-positive TNBC. Moreover, induction of a change in subtype to the AR-negative phenotype was observed after NAC.

\section{ACKNOWLEDGEMENTS}

We thank Yayoi Matsukiyo and Tomomi Ohkawa (Department of Surgical Oncology, Osaka City University Graduate School of Medicine) for helpful advice regarding data management. This study was supported in part by Grants-in-Aid for Scientific Research (KAKENHI, Nos 25461992 and 26461957) from the Ministry of Education, Science, Sports, Culture and Technology of Japan.

\section{CONFLICT OF INTEREST}

The authors declare no conflict of interest.

\section{REFERENCES}

Abd El-Rehim DM, Ball G, Pinder SE, Rakha E, Paish C, Robertson JF, Macmillan D, Blamey RW, Ellis IO (2005) High-throughput protein expression analysis using tissue microarray technology of a large well-characterised series identifies biologically distinct classes of breast cancer confirming recent cDNA expression analyses. Int $J$ Cancer 116: 340-350.

Ainbinder DJ, Esmaeli B, Groo SC, Finger PT, Brooks JP (2009) Introduction of the 7th edition eyelid carcinoma classification system from the American Joint Committee on Cancer-International Union Against Cancer staging manual. Arch Pathol Lab Med 133: 1256-1261.

Ando S, De Amicis F, Rago V, Carpino A, Maggiolini M, Panno ML, Lanzino M (2002) Breast cancer: from estrogen to androgen receptor. Mol Cell Endocrinol 193: 121-128.

Bauer KR, Brown M, Cress RD, Parise CA, Caggiano V (2007) Descriptive analysis of estrogen receptor (ER)-negative, progesterone receptor (PR)negative, and HER2-negative invasive breast cancer, the so-called triple-negative phenotype: a population-based study from the California cancer Registry. Cancer 109: 1721-1728.

Brys M, Wojcik M, Romanowicz-Makowska H, Krajewska WM (2002) Androgen receptor status in female breast cancer: RT-PCR and Western blot studies. J Cancer Res Clin Oncol 128: 85-90.

Buzdar AU, Valero V, Ibrahim NK, Francis D, Broglio KR, Theriault RL, Pusztai L, Green MC, Singletary SE, Hunt KK, Sahin AA, Esteva F,
Symmans WF, Ewer MS, Buchholz TA, Hortobagyi GN (2007) Neoadjuvant therapy with paclitaxel followed by 5 -fluorouracil, epirubicin, and cyclophosphamide chemotherapy and concurrent trastuzumab in human epidermal growth factor receptor 2-positive operable breast cancer: an update of the initial randomized study population and data of additional patients treated with the same regimen. Clin Cancer Res 13: 228-233.

Castellano I, Allia E, Accortanzo V, Vandone AM, Chiusa L, Arisio R, Durando A, Donadio M, Bussolati G, Coates AS, Viale G, Sapino A (2010) Androgen receptor expression is a significant prognostic factor in estrogen receptor positive breast cancers. Breast Cancer Res Treat 124: 607-617.

de Launoit Y, Dauvois S, Dufour M, Simard J, Labrie F (1991) Inhibition of cell cycle kinetics and proliferation by the androgen 5 alphadihydrotestosterone and antiestrogen N,n-butyl-N-methyl-11-[16' alphachloro-3',17 beta-dihydroxy-estra-1',3',5'-(10')triene-7' alpha-yl] undecanamide in human breast cancer ZR-75-1 cells. Cancer Res 51: 2797-2802.

Goldhirsch A, Wood WC, Coates AS, Gelber RD, Thurlimann B, Senn HJ (2011) Strategies for subtypes-dealing with the diversity of breast cancer: highlights of the St Gallen International Expert Consensus on the Primary Therapy of Early Breast Cancer 2011. Ann Oncol 22: 1736-1747.

Graham TR, Yacoub R, Taliaferro-Smith L, Osunkoya AO, Odero-Marah VA, Liu T, Kimbro KS, Sharma D, O'Regan RM (2010) Reciprocal regulation of ZEB1 and AR in triple negative breast cancer cells. Breast Cancer Res Treat 123: 139-147.

Gucalp A, Tolaney S, Isakoff SJ, Ingle JN, Liu MC, Carey LA, Blackwell K, Rugo H, Nabell L, Forero A, Stearns V, Doane AS, Danso M, Moynahan ME, Momen LF, Gonzalez JM, Akhtar A, Giri DD, Patil S, Feigin KN, Hudis CA, Traina TA (2013) Phase II trial of bicalutamide in patients with androgen receptor-positive, estrogen receptor-negative metastatic breast cancer. Clin Cancer Res 19: 5505-5512.

Gucalp A, Traina TA (2010) Triple-negative breast cancer: role of the androgen receptor. Cancer J 16: 62-65.

Hall JG, Solehdin F (1996) Genomic imprinting. Zhonghua Min Guo Xiao Er Ke Yi Xие Hui Za Zhi 37: 401-404.

Isola JJ (1993) Immunohistochemical demonstration of androgen receptor in breast cancer and its relationship to other prognostic factors.J Pathol 170: 31-35.

Kashiwagi S, Yashiro M, Takashima T, Aomatsu N, Kawajiri H, Ogawa Y, Onoda N, Ishikawa T, Wakasa K, Hirakawa K (2013) c-Kit expression as a prognostic molecular marker in patients with basal-like breast cancer. $\mathrm{Br} J$ Surg 100: 490-496.

Kawajiri H, Takashima T, Onoda N, Kashiwagi S, Noda S, Ishikawa T, Wakasa K, Hirakawa K (2012) Efficacy and feasibility of neoadjuvant chemotherapy with FEC 100 followed by weekly paclitaxel for operable breast cancer. Oncol Lett 4: 612-616.

Kuenen-Boumeester V, Van der Kwast TH, Claassen CC, Look MP, Liem GS, Klijn JG, Henzen-Logmans SC (1996) The clinical significance of androgen receptors in breast cancer and their relation to histological and cell biological parameters. Eur J Cancer 32A: 1560-1565.

Lehmann BD, Bauer JA, Chen X, Sanders ME, Chakravarthy AB, Shyr Y, Pietenpol JA (2011) Identification of human triple-negative breast cancer subtypes and preclinical models for selection of targeted therapies. J Clin Invest 121: 2750-2767.

Luo X, Shi YX, Li ZM, Jiang WQ (2010) Expression and clinical significance of androgen receptor in triple negative breast cancer. Chin J Cancer 29: 585-590.

Masuda H, Baggerly KA, Wang Y, Zhang Y, Gonzalez-Angulo AM, Meric-Bernstam F, Valero V, Lehmann BD, Pietenpol JA, Hortobagyi GN, Symmans WF, Ueno NT (2013) Differential response to neoadjuvant chemotherapy among 7 triple-negative breast cancer molecular subtypes. Clin Cancer Res 19: 5533-5540.

Mattie MD, Benz CC, Bowers J, Sensinger K, Wong L, Scott GK, Fedele V, Ginzinger D, Getts R, Haqq C (2006) Optimized high-throughput microRNA expression profiling provides novel biomarker assessment of clinical prostate and breast cancer biopsies. Mol Cancer 5: 24 .

Mauri D, Pavlidis N, Ioannidis JP (2005) Neoadjuvant versus adjuvant systemic treatment in breast cancer: a meta-analysis. J Natl Cancer Inst 97: $188-194$.

Metzger-Filho O, Tutt A, de Azambuja E, Saini KS, Viale G, Loi S, Bradbury I, Bliss JM, Azim Jr HA, Ellis P, Di Leo A, Baselga J, Sotiriou C, Piccart-Gebhart M (2012) Dissecting the heterogeneity of triple-negative breast cancer. J Clin Oncol 30: 1879-1887. 
Mieog JS, van der Hage JA, van de Velde CJ (2007) Preoperative chemotherapy for women with operable breast cancer. Cochrane Database Syst Rev. CD005002.

Moinfar F, Okcu M, Tsybrovskyy O, Regitnig P, Lax SF, Weybora W, Ratschek M, Tavassoli FA, Denk H (2003) Androgen receptors frequently are expressed in breast carcinomas: potential relevance to new therapeutic strategies. Cancer 98: 703-711.

Nielsen TO, Hsu FD, Jensen K, Cheang M, Karaca G, Hu Z, Hernandez-Boussard T, Livasy C, Cowan D, Dressler L, Akslen LA, Ragaz J, Gown AM, Gilks CB, van de Rijn M, Perou CM (2004) Immunohistochemical and clinical characterization of the basal-like subtype of invasive breast carcinoma. Clin Cancer Res 10: 5367-5374.

Ogawa Y, Hai E, Matsumoto K, Ikeda K, Tokunaga S, Nagahara H, Sakurai K, Inoue T, Nishiguchi Y (2008) Androgen receptor expression in breast cancer: relationship with clinicopathological factors and biomarkers. Int $J$ Clin Oncol 13: 431-435.

Panet-Raymond V, Gottlieb B, Beitel LK, Pinsky L, Trifiro MA (2000) Interactions between androgen and estrogen receptors and the effects on their transactivational properties. Mol Cell Endocrinol 167: 139-150.

Perez DR, Baser RE, Cavnar MJ, Balachandran VP, Antonescu CR, Tap WD, Strong VE, Brennan MF, Coit DG, Singer S, Dematteo RP (2013) Blood neutrophil-to-lymphocyte ratio is prognostic in gastrointestinal stromal tumor. Ann Surg Oncol 20: 593-599.

Perou CM, Sorlie T, Eisen MB, van de Rijn M, Jeffrey SS, Rees CA, Pollack JR, Ross DT, Johnsen H, Akslen LA, Fluge O, Pergamenschikov A, Williams C, Zhu SX, Lonning PE, Borresen-Dale AL, Brown PO, Botstein D (2000) Molecular portraits of human breast tumours. Nature 406: $747-752$.

Poulin R, Baker D, Labrie F (1988) Androgens inhibit basal and estrogeninduced cell proliferation in the ZR-75-1 human breast cancer cell line. Breast Cancer Res Treat 12: 213-225.

Prat A, Perou CM (2011) Deconstructing the molecular portraits of breast cancer. Mol Oncol 5: 5-23.

Rakha EA, El-Rehim DA, Paish C, Green AR, Lee AH, Robertson JF, Blamey RW, Macmillan D, Ellis IO (2006) Basal phenotype identifies a poor prognostic subgroup of breast cancer of clinical importance. Eur $J$ Cancer 42: 3149-3156.

Safarpour D, Tavassoli FA (2014) A targetable androgen receptor-positive breast cancer subtype hidden among the triple-negative cancers. Arch Pathol Lab Med 139: 612-617.

Soreide JA, Lea OA, Varhaug JE, Skarstein A, Kvinnsland S (1992) Androgen receptors in operable breast cancer: relation to other steroid hormone receptors, correlations to prognostic factors and predictive value for effect of adjuvant tamoxifen treatment. Eur J Surg Oncol 18: 112-118.
Sorlie T, Perou CM, Tibshirani R, Aas T, Geisler S, Johnsen H, Hastie T, Eisen MB, van de Rijn M, Jeffrey SS, Thorsen T, Quist H, Matese JC, Brown PO, Botstein D, Lonning PE, Borresen-Dale AL (2001) Gene expression patterns of breast carcinomas distinguish tumor subclasses with clinical implications. Proc Natl Acad Sci USA 98: 10869-10874.

Sorlie T, Tibshirani R, Parker J, Hastie T, Marron JS, Nobel A, Deng S, Johnsen H, Pesich R, Geisler S, Demeter J, Perou CM, Lonning PE, Brown PO, Borresen-Dale AL, Botstein D (2003) Repeated observation of breast tumor subtypes in independent gene expression data sets. Proc Natl Acad Sci USA 100: 8418-8423.

Takagi K, Miki Y, Nagasaki S, Hirakawa H, Onodera Y, Akahira J, Ishida T, Watanabe M, Kimijima I, Hayashi S, Sasano H, Suzuki T (2010) Increased intratumoral androgens in human breast carcinoma following aromatase inhibitor exemestane treatment. Endocr Relat Cancer 17: 415-430.

Umemura S, Kurosumi M, Moriya T, Oyama T, Arihiro K, Yamashita H, Umekita Y, Komoike Y, Shimizu C, Fukushima H, Kajiwara H, Akiyama F (2006) Immunohistochemical evaluation for hormone receptors in breast cancer: a practically useful evaluation system and handling protocol. Breast Cancer 13: 232-235.

Wang Y, Waters J, Leung ML, Unruh A, Roh W, Shi X, Chen K, Scheet P, Vattathil S, Liang H, Multani A, Zhang H, Zhao R, Michor F, Meric-Bernstam F, Navin NE (2014) Clonal evolution in breast cancer revealed by single nucleus genome sequencing. Nature 512: 155-160.

Wolff AC, Hammond ME, Hicks DG, Dowsett M, McShane LM, Allison KH, Allred DC, Bartlett JM, Bilous M, Fitzgibbons P, Hanna W, Jenkins RB, Mangu PB, Paik S, Perez EA, Press MF, Spears PA, Vance GH, Viale G, Hayes DF (2013) Recommendations for human epidermal growth factor receptor 2 testing in breast cancer: American Society of Clinical Oncology/ College of American Pathologists clinical practice guideline update. J Clin Oncol 31: 3997-4013.

Wolff AC, Hammond ME, Hicks DG, Dowsett M, McShane LM, Allison KH, Allred DC, Bartlett JM, Bilous M, Fitzgibbons P, Hanna W, Jenkins RB, Mangu PB, Paik S, Perez EA, Press MF, Spears PA, Vance GH, Viale G, Hayes DF (2014) Recommendations for human epidermal growth factor receptor 2 testing in breast cancer: American Society of Clinical Oncology/ College of American Pathologists clinical practice guideline update. Arch Pathol Lab Med 138: 241-256.

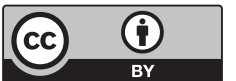

This work is licensed under the Creative Commons Attribution 4.0 International License. To view a copy of this license, visit http://creativecommons.org/licenses/by/4.0/ 